\title{
Social Enterprises in Serbia: Analysis of Key Development Factors, Major Actors and their Relationships
}

DOI: 10.7595/management.fon.2016.0030

\begin{abstract}
In this paper we present evidence from the empirical research which focuses on social entrepreneurship (SE) in Serbia. We analysed the key factors that influence the development of social enterprises, the major actors in the sector and the relationships established among them. Our data show that owners are the dominant stakeholder group influencing SE business and that they are followed by the customers. The influence of the market vs the influence of the regulations changes with the change in size of the enterprise. The importance of the state also changes with the change in size. Though social enterprises operate in the network characterised by the trust among the actors, high quality cooperation and embeddedness into a network of closely tied business relations, the level of influence that sector itself has is perceived very low.
\end{abstract}

Keywords: social enterprises, key actors, networks, financial support, the role of state

\section{Introduction}

The term social enterprise (SE) is universally used to name those organizations that have an economic activity organized for the purpose of social benefit. The most frequently used definition of social enterprises is the one suggested by the European Research Network for Social Economy (EMES) which says that "Social enterprises are non-profit private organizations dealing with producing of goods and rendering of services, which is directly linked with their clear objective that the community should benefit from their activity. They rely on collective dynamics, while involving different types of stakeholders into their management bodies; they highly value their autonomy and take the economic risk associated with their activities." This implies that to be considered as such, social enterprises should care to balance their economic with their social dimensions (Battilana et al., 2012). Just like any other organization, social enterprises do not operate in isolation, they are rather embedded in a network of interacting individuals, groups and other organizations which are usually named as stakeholders (Hatch, 2006),. Social enterprises embrace multiple stakeholders in their pursuit of social missions through business ventures (Gonin et al., 2012).

Mapping of social enterprise economy showed that there were 1,196 social enterprises operated in Serbia in 2014 (SORS, 2014). Though recent research support the argument that social enterprises sector is growing in Serbia (Babović et al, 2008; Cvejić et al, 2008; Cvejić, 2013; Shrestha, 2013), in terms of its contribution to national economy, employment and social impact the sector is still small

(SORS, 2014). Previous research in the field of SEs made an effort to conceptualize SE 'ecosystems' (Luhmann, 1989; Salamon et al, 2003; Arthur et al, 2006; Doherty et al, 2009; Grassl, 2012; Roy et al, 2015; Hazenberg et al, 2016). However, we do not know much about peculiarities of the ecosystem in which so-

\footnotetext{
1 Ekonomski fakultet, Univerzitet u Beogradu, anaa@ekof.bg.ac.rs
}

2 Ekonomski fakultet, Univerzitet u Beogradu, gkrstic@ekof.bg.ac.rs 
cial enterprises in Serbia operate, and even more, we do not have much empirical data about it. A very recent research by Hazenberg et al (2016) provides evidence for the existence of four social enterprise ecosystem types across Europe: Statist-macro, Statist-micro, Private-macro and Private-micro. Differences in these main types are based on the level of engagement of the state, of the third and private sector stakeholders, as well as on the relative geographic placement of the ecosystems (local; national; international). According to them, Serbia belongs to Statist-macro ecosystem type, which is characterised by higher homogeneity in the types of social enterprises that emerge and lower commercial sustainability as mostly reliant on grant and/or directed funding. The lack of localism and the lack of collaboration among stakeholders at the macro- and micro levels is also notable.

Shrestha (2013) argues that the level of the development of social entrepreneurship within national economy can be determined based on the analysis of the following factors: actors (social enterprises, CSOs, government, businesses, financial institutions), legislative framework (legal forms of social enterprises, subsidies, tax exemptions...), existence of the financial schemes, instruments, incentives for the SEs, networking/partnerships, capacities of the social enterprises (management and other skills) and awareness raised among citizens (best examples, informative and education). Shrestha argues that these factors overlap, influence each other and are in correlation, and at certain level of development all together indicate the stage in the development of social entrepreneurship.

In this paper we present evidence from the empirical research which explores the level of development of the factors named above which, according to Shrestha (2013), indicate the stage in the development of social entrepreneurship. We explore the position of each of the identified key stakeholders in accordance with the firm's size, corresponding degree of the influence they have in business operations and channels of their engagement. We proceed with the analysis of social and financial capital embedded in the SE network, capacities of SEs in terms of managerial and other skills and finish with questioning the awareness about the overall importance of the social enterprise sector. In that manner, this paper contributes to the existing corpus of knowledge about the SE sector in Serbia by bringing out empirical data generated through field research. In the next section, we explain the methodology the research used, and proceed with research findings and the development of a stakeholder's map. We conclude by summarizing the main findings about the key factors, actors and network of relationships and their implications on the development of social enterprises.

\section{Methodology}

This study is based on quantitative and qualitative data drawn from the field research that started in June 2014. A survey of social enterprises was conducted in Serbia from June to October 2015. The sample covered 90 social enterprises: 30 from the capital city of Belgrade and 60 from other parts of the country. The sampling frame was based on a representative list of 1196 social enterprises in Serbia, established by the Statistical Office of the Republic of Serbia ${ }^{3}$ (SORS, 2014). The initial sample was selected using the simple random sampling method. The respondents are individuals aged 18 years and over.

Social enterprises in the sampling frame are defined following the EMES methodology by indicators relating to the economic, social and management dimension. Data collection was conducted by e-mail. The questionnaire was sent to selected social enterprises together with an explanation which introduced the purpose of the survey and the benefits gained from their participation in it. The questionnaire consists of several modules. The first three modules are designed to capture data on personal characteristics of respondents (such as gender, age, education, previous experience in founding/managing a social enterprise, motivation etc.), as well as on general characteristics of the enterprise (such as its type, size according to the number of employees, ownership structure, year of establishment, sector of economic activity, sales turnover, etc.). The other modules are devoted to the following dimensions of social enterprises: access to financing, main challenges and constraints for social enterprises, the role of innovation during the life-cycle of the enterprise, the influence of different categories of stakeholders on the decision-making process of the enterprise and the social

${ }^{3}$ Under the project of the European Commission "Economic Impact of Social Enterprises" 
capital of entrepreneurs. In order to understand the view of major actors in the "third sector" we interviewed representatives from different ministries, from the local government and other relevant stakeholders (NGO sector, media, and financial sector) whom we consider to be the most involved and appropriate to represent the views of the whole sector. We used these field data in order to develop a stakeholders' map (Map 1).

\section{Empirical Results}

This section examines the social and financial capital embedded in the SE network, capacities of SEs in terms of managerial and other skills and awareness about the overall importance of the social enterprise sector.

Actors. The owners/the board of directors are recognized as the most influential actors in the SE sector as $77 \%$ of respondents believe that they are very or extremely important in the decision-making process. Customers/users and employees are also very or extremely important but for a lower percentage of respondents (47\% and $40 \%$, respectively). Less influential are shareholders and state and public administration (33\% and $28 \%$, respectively). As far as the third sector, suppliers and the community are concerned, the majority of interviewees have reported that they are not at all influential (between $30 \%$ and $46 \%$; Figure 1).

The stakeholder's degree of influence according to the size of the enterprise is presented in Figures 2 and 3. The owners and the board of directors, as well as customers seem to be of great importance in the decision making process for micro and small enterprises. Owners and the board of directors are considered to be very or extremely influential by $76 \%$ of micro companies and $80 \%$ of small companies, while for customers the corresponding percentages are $46 \%$ and $50 \%$. Among small enterprises, the state and public administration is also influential (50\%). Less influential stakeholders appear to be the third sector and the community in both micro and small enterprises, which is also the case for the state and public administration in micro enterprises and for employees in small enterprises. Shareholders and suppliers are not influential at all according to $43 \%$ and $38 \%$ of respondents respectively in micro enterprises and to $60 \%$ and $30 \%$ of respondents respectively in small enterprises. ${ }^{3}$

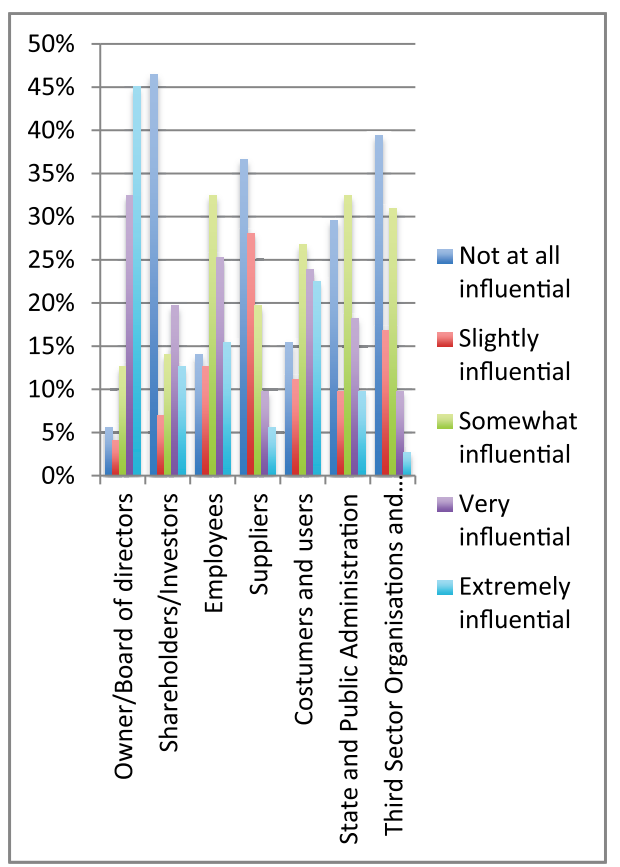

Figure 1: Stakeholders' degree of influence

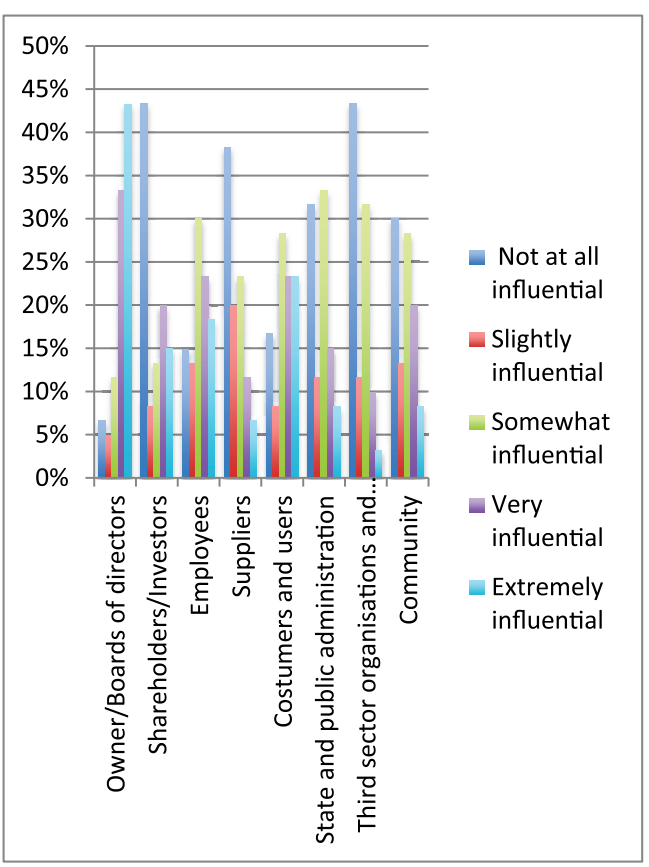

Figure 2: Stakeholders' degree of influence, Micro SEs 


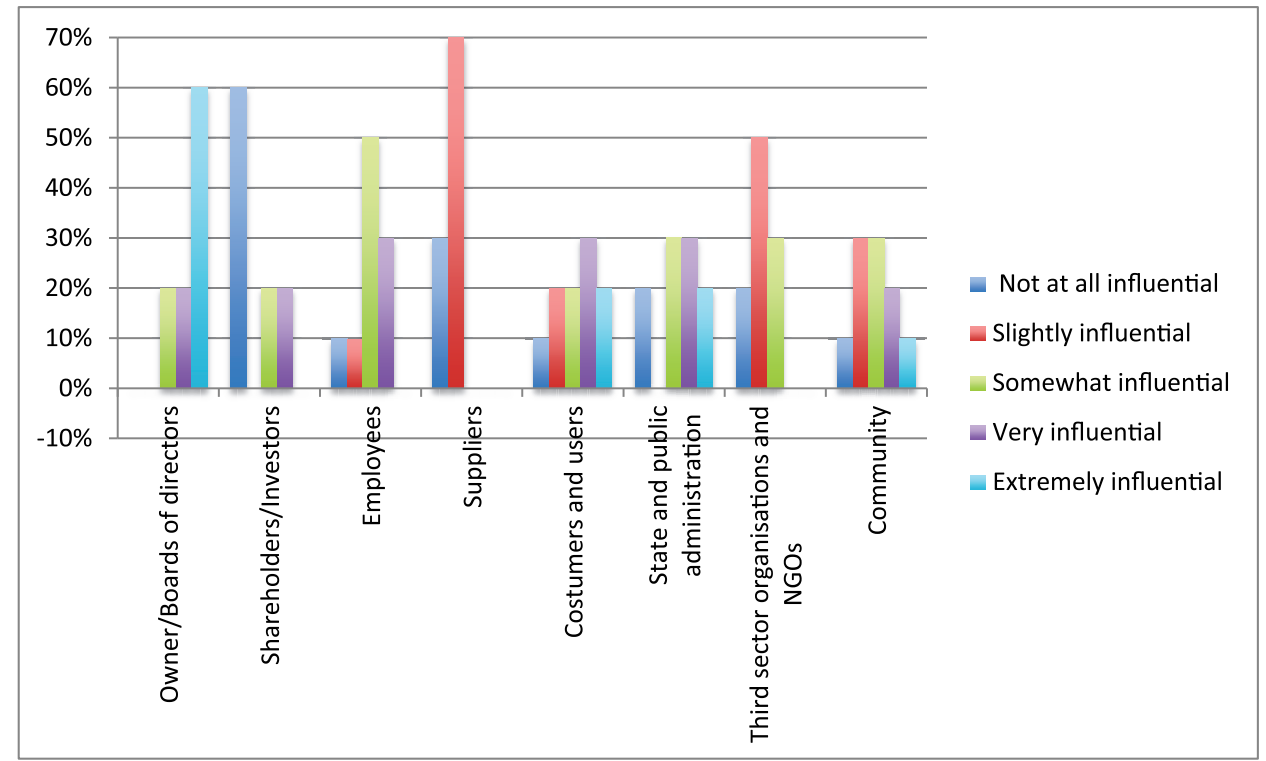

Figure 3: Stakeholders' degree of influence, Small SEs

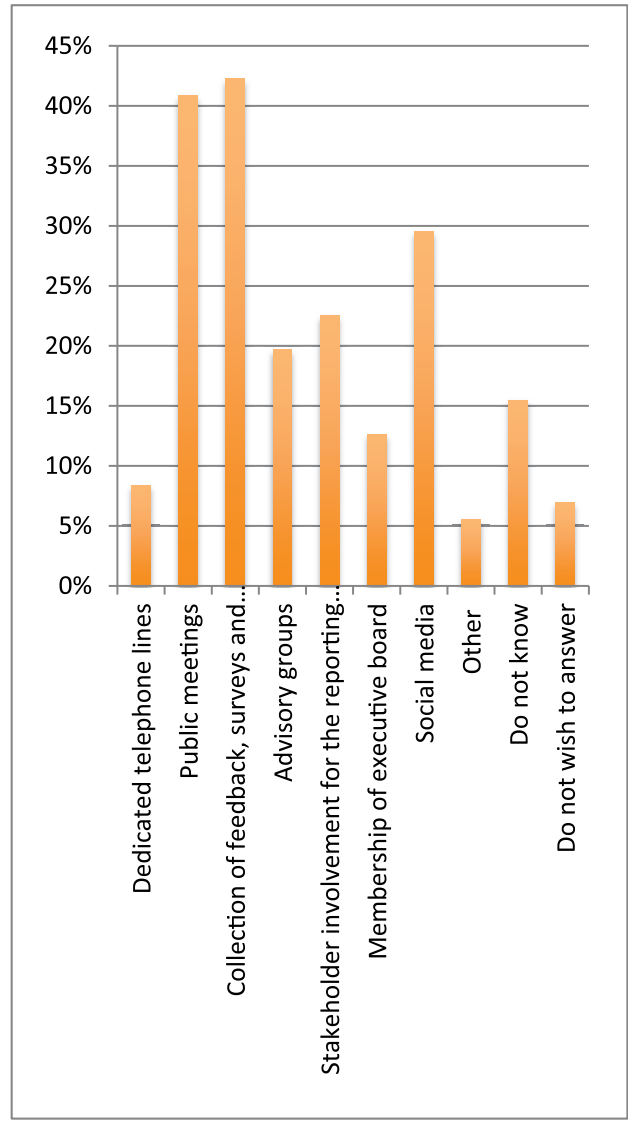

Figure 4: Stakeholders' engagement practices

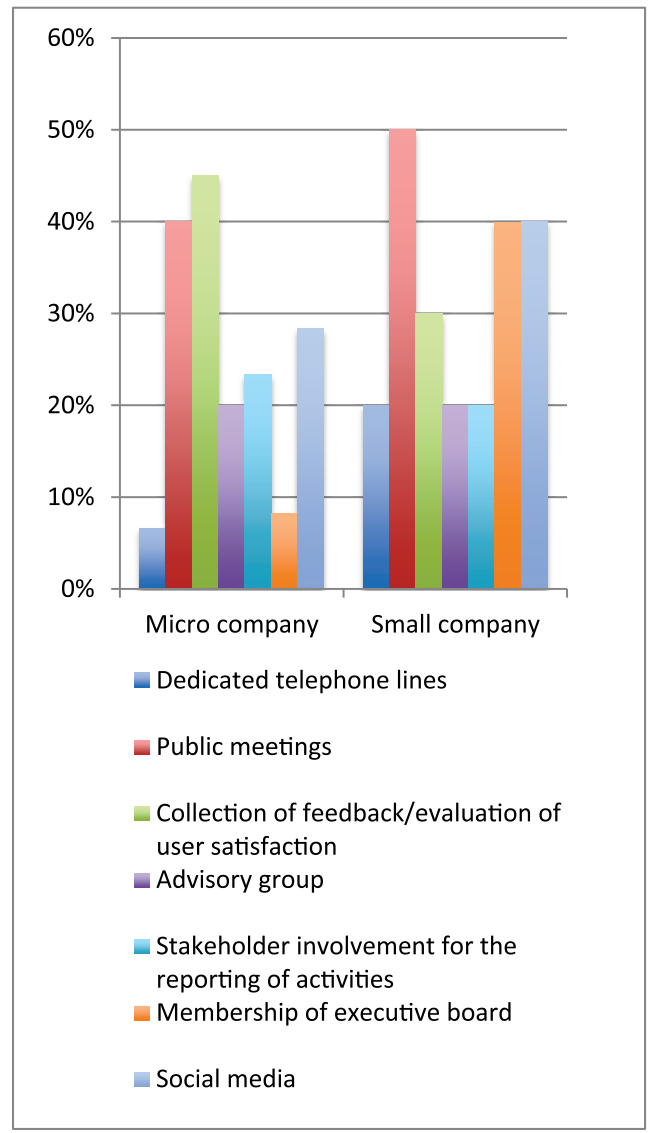

Figure 5: Stakeholders' engagement practices per business size

Source: Own calculations from survey data 
Channels of engagement. The main channels used to engage stakeholders in the activities of an enterprise are shown in Figure 4. The most common stakeholder engagement practices are collection of feedback, surveys and evaluation of users' satisfaction, followed by the organization of public meetings, the use of social media, stakeholder involvement in the reporting activities and advisory groups. Just $13 \%$ of enterprises rely on membership of executive boards and $8 \%$ arrange dedicated telephone lines. According to the size of the enterprise, micro enterprises mainly use public meetings and the collection of feedback or evaluation of user satisfaction methods to engage stakeholders in their activities (Figure 5). Small companies mainly rely on public meetings, membership of executive boards or social media.

Networks. Several national networks of NGOs and social entrepreneurs exist in Serbia, as well as the recently established regional network called Social Entrepreneurship Forum. There is an initiative called the SENS network - Social Economy Network Serbia, which is the only national network that brings together social enterprises. The SENS was founded in 2011 by the Group 484, with the support of the Italian UniCredit Foundation, which has a long tradition of funding and supporting the social entrepreneurship sector throughout Southeast Europe. The SENS currently has 26 members from all over Serbia, including citizens associations, enterprises for vocational rehabilitation of persons with disabilities, limited liability companies and cooperatives. However, at the moment, the SENS is only at the stage of providing information for social enterprises, while other important functions that can be performed are not covered. This subsection analyses the social capital of entrepreneurs based on five statements concerning relationships between team members, their cooperation and the network of business relations of the enterprise. When asked if "In my team people generally trust each other", $79 \%$ of the respondents supported (completely or largely) the statement. Similarly, $84 \%$ of respondents confirmed that they generally trust people in their team (completely or largely). The quality of team cooperation is seen as effective by $79 \%$ of the respondents. The percentage of individuals who completely or largely support the statement that they generally co-operate with their team members is even higher (92\%). Finally, over half of the respondents supported a statement that their enterprise has a large network of business relations.

Existence of the financial schemes, instruments and incentives for the SEs. All sources of funding available to social enterprises are shown in Figure 6. Grants from projects and donations or fundraising are accessible to $49 \%$ and $46 \%$ of respondents, respectively, $37 \%$ of respondents borrow from banks, $26 \%$ rely on private investments and $24 \%$ rely on personal savings. Age distribution of respondents in terms of availability of various sources of funding is presented in Figure 7. The percent of respondents who reported accessibility to specific funding sources increases from the youngest age group (18-30) up to the age group between 41-50 years of age, and then decreases towards the oldest individuals $(60+)$. This relationship is observed for most funding sources, except for social investments where no age differences between respondents exist and for private investments also which are available mostly for respondents between 31 and 40 and between 51 and 60 years of age. The distribution of enterprises by their size for each available source of funding is shown in Figure 8. It is obvious that there are no significant differences in the distribution of enterprises by size among different funding sources. All sources of funding are predominantly accessible by micro enterprises, as they represent $88 \%$ of the sampled enterprises (from $67 \%$ for crowdfunding to $90 \%$ for personal savings and private investments). Consequently, the remaining share of funding accessibility to small enterprises is lowest for personal savings, microcredits and private investments (from $5 \%$ to $10 \%$ ), while highest for crowdfunding and social investments (33\%). 


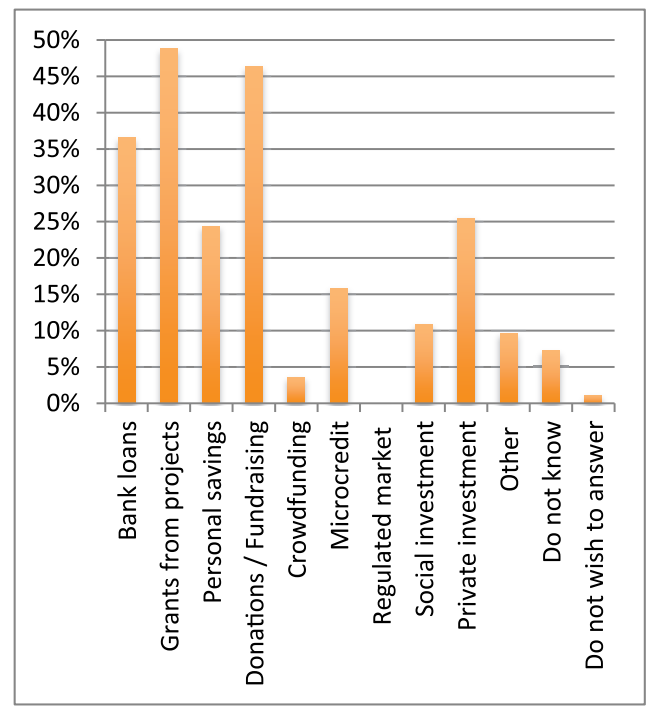

Figure 6:. Available sources of funding

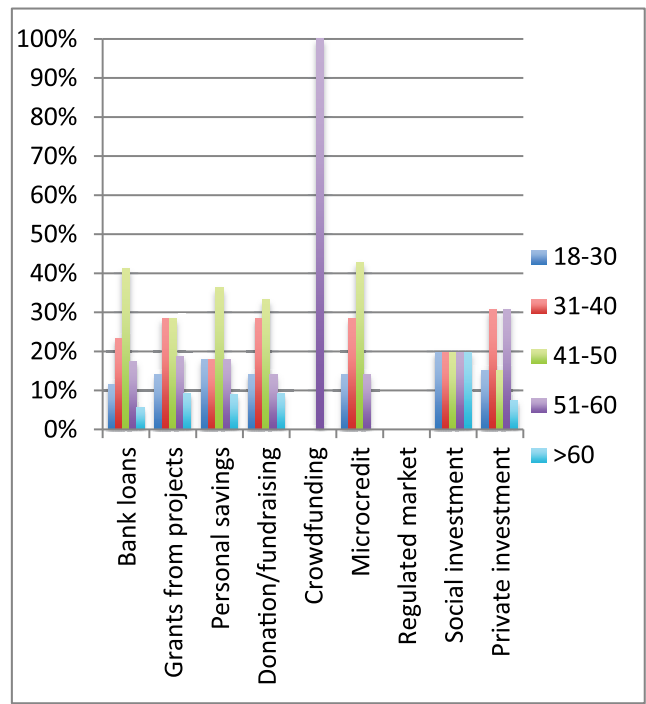

Figure 7: Available sources of funding by age of respondents

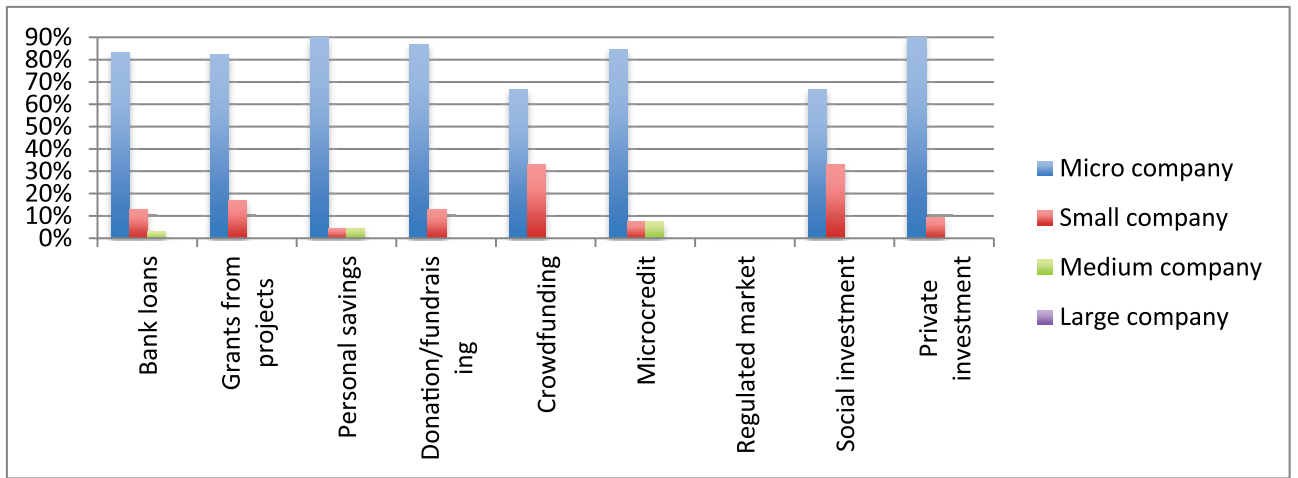

Figure 8: Available sources of funding per SEs' size

Source: Own calculations from survey data.

Regarding the actual sources of funding, $45 \%$ of the respondents use project grants as their main source of funding, $30 \%$ rely on donations or fundraising, $17 \%$ support their activities using personal savings and $17 \%$ using private investments, while bank loans are a financing instrument for $13 \%$ of enterprises (Figure 10). The percentage of respondents who raised money through crowdfunding, microcredits and regulated markets is negligible. Significant differences exist between potential and actually used funds by all sources, except for project grants. Project grants are available for $49 \%$ of respondents and they are used by $45 \%$ of respondents. In contrast, bank loans are available for $37 \%$ of respondents, but only $13 \%$ of respondents have actually used them. The main financing sources used in the start-up phase of the social enterprise are presented in Figure 9. Most enterprises (35\%) relied on grants from projects to finance their start up activities, personal savings $(29 \%)$ and donations or fundraising $(28 \%)$. Other important sources of funding are private investments (18\%) and bank loans (11\%). This low rate of bank loans is due to very unfavorable conditions for lending money through banking channels in Serbia (i.e., interest rate, substantial collateral etc.). Other financing instruments are negligible (11\%), while microcredits or crowdfunding do not exist.

Age distribution of the respondents according to actual funding sources is presented in Figure 10. Personal savings, bank loans and microcredits are the predominant financing instruments for respondents between 41 and 50 years of age (from $46 \%$ up to $100 \%$ ), while grants from projects and donations are mainly used by the younger age group, between $31-40$ old ( $40 \%$ and $30 \%)$. Regulated markets are used only by the youngest respondents (18-30), while social investments are equally important for the youngest respondents 
and those aged between 51-60 (50\%). As regards the business size, almost all sources of funding are predominantly used by micro enterprises, as in the case of accessibility of these sources, except microcredits and social investments which are equally important financing instruments for both micro and small enterprises (Figure 11). Bank loans are predominantly used as a financing instrument by totally financially independent enterprises $(64 \%)$, while donations, grants from projects and personal savings are mainly used by not independent enterprises (from $43 \%$ to $68 \%$ ). Crowdfunding and microcredits are equally important financing sources for partially financially independent and not independent enterprises (Figure 12), while private investments are approximately equally important for all three categories of enterprises according to their financially independent status.

Capacities of the social enterprises (management and other skills). Difficulties in the field of human resources (difficulties in recruiting employees and volunteers, difficulties in drafting a business plan, the low motivation, skills and work experience of employees) do not appear to be among the three most important constraints that affected the development of the enterprise neither in the start-up nor in the current development stage. Low skills and lack of experience of employees faced $13 \%$ of enterprises in the initial phase, while only $3 \%$ of enterprises reported this as the current constraint. Difficulties in recruiting employees and low motivation faced some $8 \%$ and $6 \%$ of enterprises, respectively, and they remained the constraints for the same share of enterprises in the current development stage. However, future prospects appear better than the current ones in all these segments of human capital challenges.

Raising awareness. The awareness about the importance of social enterprises, their social and economic importance and the role they have in employment and development of entrepreneurship is still not adequately developed. Our results suggest that $15 \%$ of enterprises perceived limited public awareness of the enterprise and trust in their activities as constraint in the start-up phase, only $4 \%$ of enterprises view that as a current constraint and $1 \%$ as a future constraint. These results concerning improved perception of social enterprises seem quite optimistic, bearing in mind that today policy makers perceive social enterprises as a potential solution to employment of vulnerable groups, while other positive impacts of this sector are mostly neglected (Lebedinski, 2014). Media can play a crucial role in the development of a public knowledge and awareness, but their involvement in this issue is still modest.

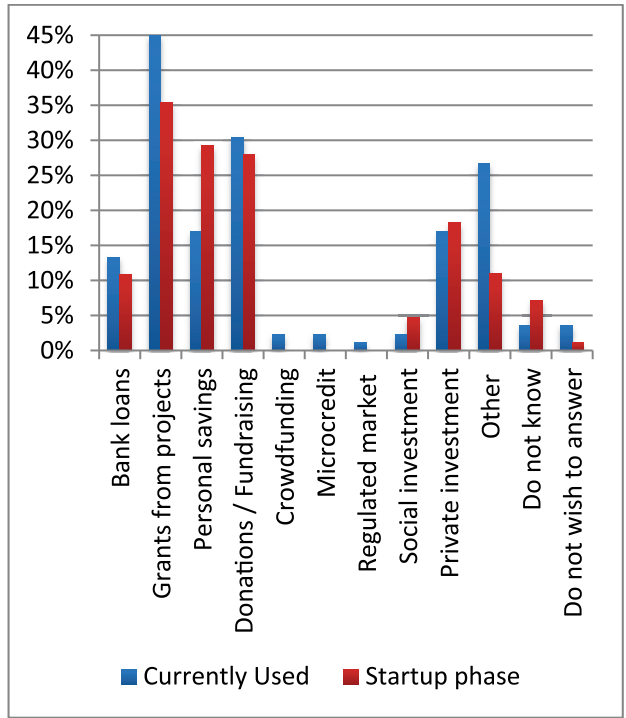

Figure 9: SEs' funding

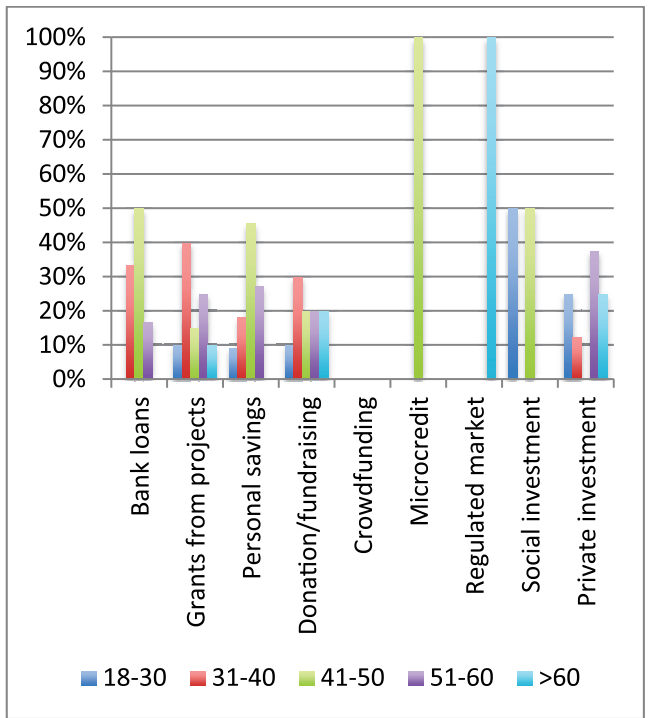

Figure 10: Funding currently used. Age distribution 


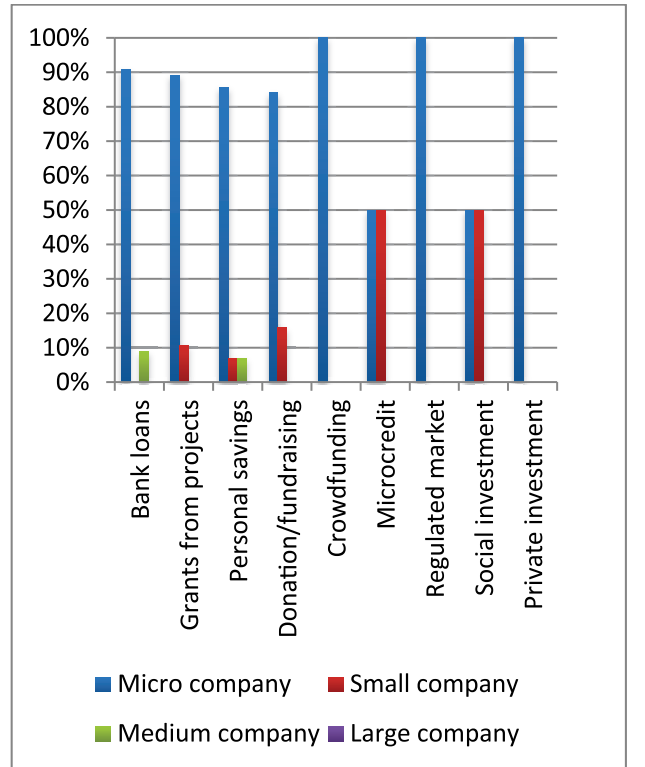

Figure 11. Funding currently used per SEs' size

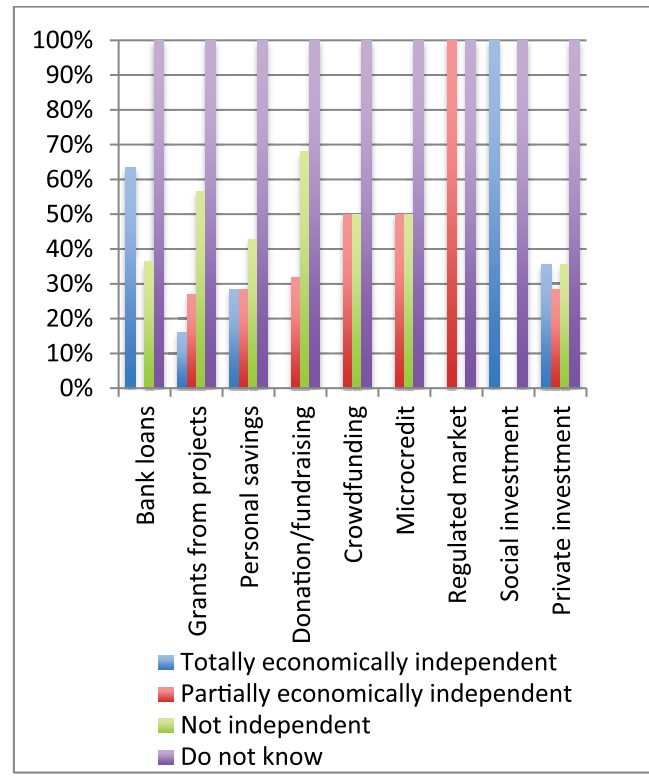

Figure 12. Funding currently used by SEs' economic independence

Source: Own calculations from survey data.

\section{Stakeholders'map}

Based on qualitative data generated from the questionnaire and qualitative field data, we constructed a map of the key stakeholders in the SE sector and their mutual relationships (Map 1). The following points are important to consider when viewing the stakeholder map: The horizontal $(x)$ axis represents where the stakeholder belongs within the market economy (i.e., public, third or private sectors) and runs from the public sector (State) on the left (negative) to the private sector (Market) on the right (positive) part of the x-axis. The third sector is placed in the middle of the $x$-axis (i.e., around $x=0$ ). The vertical $(y)$ axis represents the geographic level of operation of the stakeholder group ranging from local to national to global and runs from the local (negative y-axis) up to the global (positive y-axis). The national level is placed between these two levels around $y=0$. It should be noted that whilst global can relate to truly international stakeholders, it mainly refers here to trans-national stakeholders operating within Europe. Stakeholders are also represented along the $\mathrm{x}$-axis by the colour of their particular box. Therefore: State-based stakeholders are represented by blue boxes, third-sector stakeholders are represented by pink boxes, private sector stakeholders are represented by green boxes.

The following key applies to the coloured lines representing the relationships between different stakeholder groups:

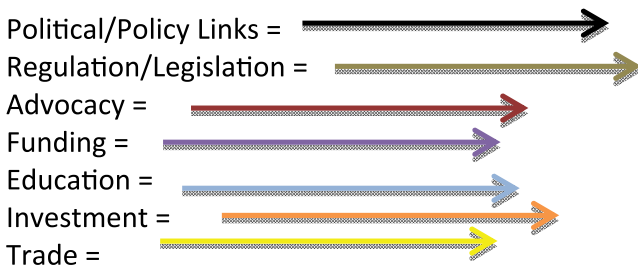




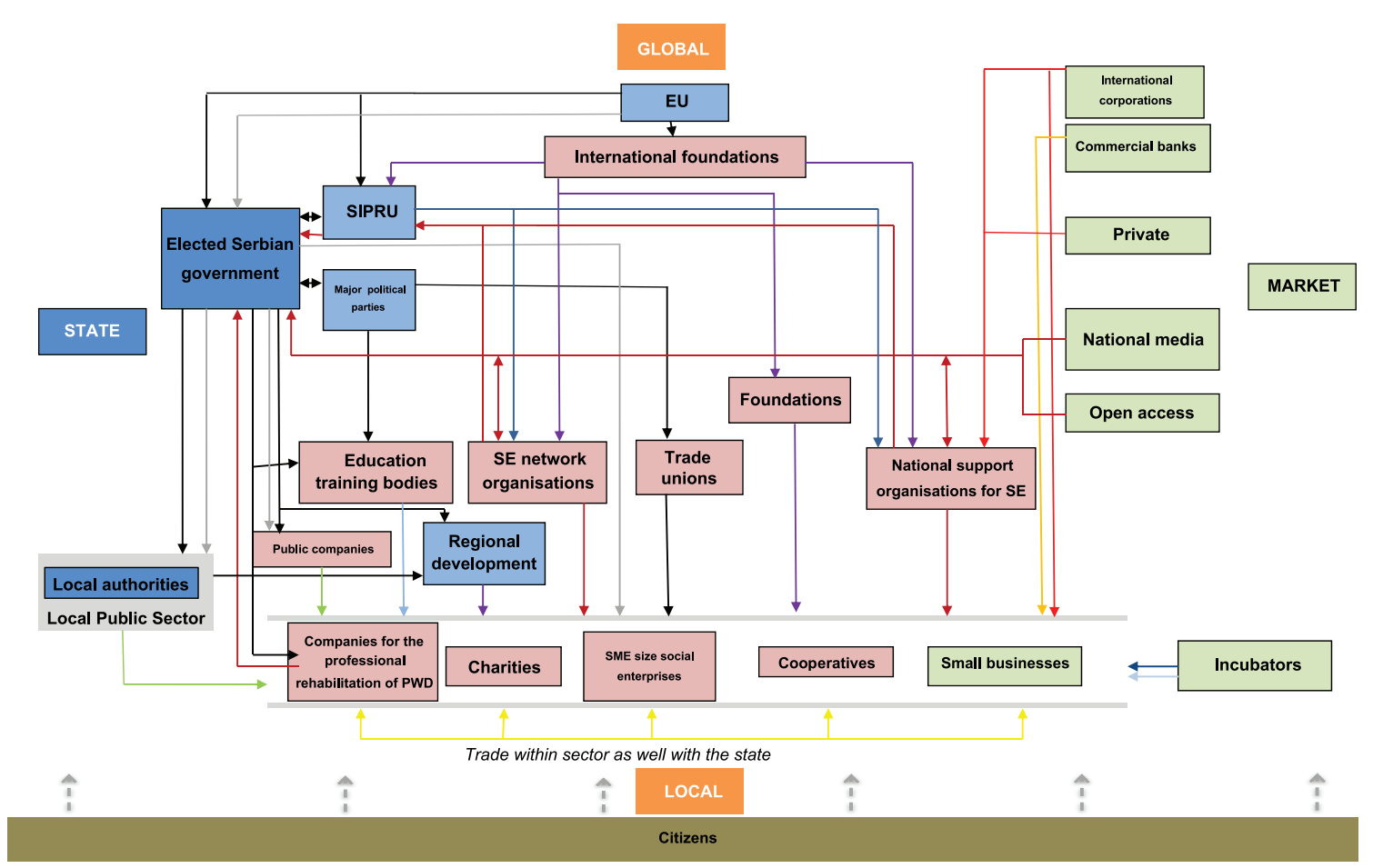

Discussion and Conclusion

The social economy sector is young and emerging in Serbia. Previous research in the field (Vuković, 2013, Shrestha 2013, Cvejić, 2013, Cvejić, 2016) argue that with certain changes in legislative framework, such as the introduction of social cooperatives and the recognition of social enterprises as service providers in social care, the SE sector in Serbia is entering its institutionalization stage. Previous research also stresses out that this stage it is of utmost importance to recognize which are the strengths and the weaknesses of the sector in order to design adequate policy measures to support SEs.

Our data show that:

Finding 1: $\quad$ Owners are the dominant stakeholder group in influencing SE business. They are followed by the customers, which implies that SEs regard the power of the market in profiling organization's future even higher than the power of policy makers and other stakeholders.

Finding 2: $\quad$ The influence of the market vs the influence of the regulations changes with the change in organisation's size: micro SEs report the importance of customers more than the importance of the state, but this changes as the organization grows. The importance of the state changes with the change in size of the enterprise in a way that the state becomes a more important actor in the decision-making process as social enterprise grows in size. This is due to the fact that the organisation's early development is tested by market acceptance; once market is recognized and basic relations are established, regulation becomes more important for enabling further growth.

Finding 3: $\quad$ The level of influence that the sector itself has is perceived as very low. This should be used as an information for those in charge of building up this sector to ensure to create conditions for enhancing bottom-up initiatives of sector development.

Finding 4: $\quad$ The business sector does not sufficiently recognize the importance of its role in the development of the third sector. A much better cooperation with the corporate sector, especially large companies which have adopted corporate social responsibility policies and practices is necessary. 
Finding 5: $\quad$ Networks are an important instrument to support social enterprises because through them members come to high quality information on various business topics, acquire new knowledge and learn faster. Both personal and professional networks are of great importance in the development of social entrepreneurship. Although our analysis has showed that social enterprises operate in the network characterised by the trust among the actors, a high quality cooperation and embeddedness into a network of closely tied business relations, inter-organizational networks among social entrepreneurs, companies and relevant stakeholders surrounding the sector are not developed enough and are not sufficiently articulated.

Finding 6: $\quad$ Training and education to support social entrepreneurship should give a strong basis and equip social entrepreneurs with the required skills to compete on the market. Some educational services are available but social entrepreneurs have voiced their opinion that they would need targeted training for social entrepreneurship. An additional obstacle is that the formal education does not sufficiently equip young people with required managerial skills for doing SE business.

Finding 7: $\quad$ Social enterprises face an unfavourable access to financial resources.

\section{REFERENCES}

[1] Arandarenko, M. et al. (2010). Polozaj ranjivih grupa na trzistu rada Srbije, UNDP.

[2] Arthur, L.,Keenoy, T. and Scott Cato, M. (2006), „Where is the Social in Social Enterprise?", paper presented at the 3rd Annual Social Enterprise Research Conference, London: South Bank University.

[3] Babovic, M, Cvejic, S, Nusic, O, Pavlovic, O. (2008) Promoting the Role of Social Enterprises in Serbia, in Borzaga, C, Galera, G and Nogales, R, eds. Social Enterprise: A new model for poverty reduction and employment generation. Bratislava: UNDP and EMES. pp 104- 142.

[4] Battilana, J., Lee, M., Walker, J., \& Dorsey, C. 2012. In search of the hybrid ideal. Stanford Social Innovation Review , Summer 2012: 51-55.

[5] Cvejic, S, Babovic, M., Vukovic, O. (2008) Mapiranje socijalnih preduzeca u Srbiji, Beograd: UNDP.

[6] Cvejic, S. (2013). Public Policies as a Framework for Development of Social Entrepreneurship in Serbia (pp 48-61) in Cvejic, S. (Eds) Cooperatives and Social Enterprises in Europe and in Transitional ContextsSociological Association of Serbia and Montenegro and Institute for Sociological Research, University of Belgrade

[7] Cvejic, S. (2016). Socijalna ekonomija: pojam i praksa u Srbiji. Cigoja stampa

[8] Gonin, M., Besharov, M., Smith, W ., \& Gachet, N. (2012). Managing social-business tensions: A review and research agenda for social enterprise [Electronic version]. Retrieved [18.11.2016] from Cornell University, ILR school site: http://digitalcommons.ilr.cornell.edu/articles/919

[9] Grassl, W., (2012), Business Models of Social Enterprise: A Design Approach to Hybridity,ACRN Journal of Social Entrepreneurship Perspectives, 1(1), pp.37-60.

[10] Hatch, M.J., (2006) Organization Theory, Oxford University Press

[11] Hazenberg,R., Bajwa -Patel,M.,Mazzei, M., Roy, M.J. and Baglioni, S. (2016) The Role of Institutional and Stakeholder Networks in Shaping Social Enterprise Ecosystem in Europe. Social Enterprise Journal 12 (3).

[12] Kolin, M. (2013). Main Types of Social Enterprises in Serbia (pp 79-86) in Cvejic, S. (Eds) Cooperatives and Social Enterprises in Europe and in Transitional Contexts (pp 62-79) Sociological Association of Serbia and Montenegro and Institute for Sociological Research, University of Belgrade

[13] Luhmann, N., (1989), Ecological communication, University of Chicago Press, Chicago.

[14] Lebedinski, L., (2014). Social Enterprise, Social Innovation and Social Entrepreneurship in Serbia: A National Report for the EFESEIIS http://www.fp7-efeseiis.eu/national-reports/

[15] Roy, MJ, McHugh, N., Huckfield, L., Kay, A. and Donaldson, C. (2015) "'The Most Supportive Environment in the World'? Tracing the development of an Institutional 'Ecosystem' for Social Enterprise." Voluntas, 26(3), pp. $777-800$.

[16] Salamon, L.M., Sokolowski, S.W., and associates, 2004. Global civil society; dimensions of the nonprofit sector. Vol. 2. Bloomfield, CT: Kumarian Press. 
[17] Shrestha, M. (2013). Factors of Development of Social Entrepreneurship In Serbia (pp. 34-47) in Cvejic, S. (Eds) Cooperatives and Social Enterprises in Europe and in Transitional Contexts (pp 62-79) Sociological Association of Serbia and Montenegro and Institute for Sociological Research, University of Belgrade

[18] Statistical Office of the Republic of Serbia (2014). Economic Impact of Social Enterprises in the Republic of Serbia.

[19] Statistical Office of the Republic of Serbia (2015). Labour Force Survey in the Republic of Serbia, 2015, Bulletin 608.

[20] Statistical Office of the Republic of Serbia, SORS (2014). Economic Impact of Social Enterprises in the Republic of Serbia. Statistical Office of the Republic of Serbia, Belgrade.

[21] Vukovic, D. (2013). Social economy, civil society and the Serbian Welfare System. in Cvejic, S. (Eds) Cooperatives and Social Enterprises in Europe and in Transitional Contexts (pp 62-79) Sociological Association of Serbia and Montenegro and Institute for Sociological Research, University of Belgrade

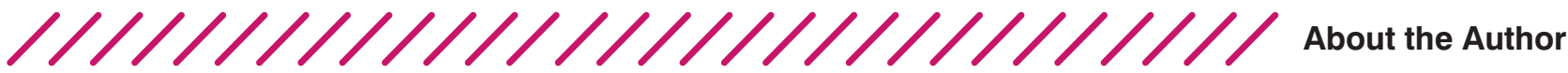

\section{Ana Aleksić Mirić \\ University of Belgrade, Faculty of Economics anaa@ekof.bg.ac.rs}

Ana Aleksić Mirić is an Associate Professor at the Faculty of Economics, University of Belgrade. She holds MSci and PhD degrees from the Faculty of Economics, University of Belgrade. During her PhD education she was a visiting scholar on Duke University,

Fuqua School of Business, USA and Carnegie Mellon University, USA. She has been involved in a number of research projects financed by the European Union, World Bank Institute and Serbian Government in the domain of the effects the reforms within Serbian economy have on growth, employment, competitive market structure and competitiveness of firms. She is experienced in business consulting to both private and public organizations. She has a rich publishing record of book chapters and articles in international and national volumes.

\section{Gorana Krstić \\ University of Belgrade, Faculty of Economics gkrstic@ekof.bg.ac.rs}

Gorana Krstić is an Associate Professor at the Faculty of Economics, University of Belgrade. She obtained her PhD degree in Economics at the School of Social Sciences, Sussex University in 2002. Her main research interests are the labour markets, informal economy, poverty, inequality and social policy. She has published (and edited) 16 monographs in these fields and has had more than 40 articles published in both national and international journals. She has been consulting short and long term for leading international agencies, including the World Bank, UNDP, ILO, EC and USAID. She has won a few competitions for individual and institutional research for which she was the team leader (the National Bank of Serbia, the Vienna Institute for International

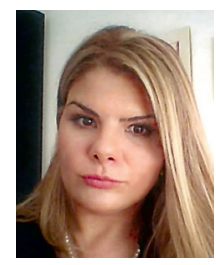
Studies, UNDP, UN, USAID). 